\title{
The Chilean Left and the Question of Democratic Transition ${ }^{1}$
}

\author{
Laurie Adkin and Catherine Hyett
}

In the context of profound, world-wide economic crisis, socialist forces are critically re-valuating past strategies. This process has produced analyses of gradualist strategies from Eurocommunism to the popular revolutionary models of Central America. A common reference point in these debates has been the experience of the Chilean Popular Unity (UP) government of 1970 to 1973. Not only the Chilean, but also the European and North American left, have tried to derive 'lessons' from the Chilean experience for their own struggles.

The UP, an electoral coalition including the Socialist, Communist, and a number of smaller social democratic and radical left parties, assumed office on a narrow, working class base, and largely because of the disunity of the bourgeois parties. The UP government adopted a strategy of gradual structural reforms aimed at winning over the petit bourgeois (or 'middle') strata, thereby isolating monopoly capital and large landowners. The left parties were divided, however, over the pace of implementation of the programme, the appropriate role for mass organisations, and the nature of the alliance strategy itself. Subsquently the bourgeois parties - the National Party (PN) and the Christian Democratic Party (PDC) - joined forces in a strategy of 'hemming in' the UP government with institutional and legal barriers, while carrying out a sustained ideological campaign aimed at re-establishing a centre-right hegemonic bloc. By 1973 the parties and class organisations of the grande bourgeoisie had succeeded in asserting their leadership over large sectors of the petite bourgeoisie. The creation of this mass base was the necessary precondition for the success of the bourgeoisie's appeal for military intervention.

The coup of September 1973 and its aftermath have profoundly influenced the practice of forces pursuing a gradualist strategy of socialist transition elsewhere.

Because of space limitations, a number of the nuances and complexities of the evolving situation in Chile, referred to in the longer version of this paper, have been omitted here.
Italian Communist Party (PCI) leaders, in the early 1970 s, saw in the Chilean experience justification for their fears that the Italian bourgeoisie might succeed in consolidating a centre-right, 'clerico-fascist' bloc. The lesson the PCI derived was the 'necessity' of forming a parliamentary alliance with the Italian Christian Democrats, commonly called the 'historic compromise'. Other left groups, by contrast, have viewed the UP's defeat as showing that a gradualist, or 'democratic' road to socialism is impossible. In this analysis we examine the crisis of the Chilean left, and the divergent strategies which are emerging for democratic and socialist transition. The Chilean experience, both before and after 1973, offers important insights into the problems and potentials of gradualist revolutionary praxis.

\section{The Opposition Projects}

In Chile today there are three contending scenarios for resolving the economic and political crisis: the 'austerity-authoritarianism' path of the military dictatorship (in alliance with financial capital and the US imperialist state); the social democratic (restricted democracy) project of the national industrial bourgeoisie represented by the opposition parties grouped in the Democratic Alliance (AD); and the revolutionary socialist programmes of the parties within the Democratic Popular Movement (MDP) and the Socialist Bloc (SB).

The monetarist economic model imposed by the military regime after 1975, which removed import tariffs, deregulated foreign investment and crippled the trade unions, has increasingly divided and weakened the regime's bourgeois bases of support. While the working class suffered a severe decline in real incomes and rising unemployment, small and medium capitalists began to feel the impact of a shrinking domestic market, competition from imports and loss of state subsidies. The organisations of national industrialists, big business and landowners also became increasingly critical of the 'Chicago boys',

IDS Bullerin, 1985, vol 16 no 2, Institute of Development Studies. Sussex 
and found sympathisers within the armed forces. Their quarrel was not so much with the political project of the regime, as with its economic policies, which were concentrating income and investment in the hands of the financial oligarchy [Chossudovsky 1977].

\section{The Christian Democrats and the Democratic Alliance}

At the end of 1977 , the PDC, whose mass base includes small and medium capital, technicos, and other 'middle' strata, began to call for a return to civilian rule. The PDC had recognised that the junta had a long-term project for restructuring the mode of capitalist accumulation, requiring a rupture with the previous consensus on national capital-led economic growth. However, it was not until 1980, when the regime imposed a new constitution reappointing Pinochet president until 1990, that the fractions of the bourgeoisie represented by the National Party (PN), the Republican Party, and the PDC began to reconverge.

By 1982, the economic crisis was severely affecting almost all sectors of national capital. In that year, industrial production fell by 22 per cent; purchasing power dropped by 15 per cent; and unemployment reached 30 per cent [Business Latin America, May 1982; South, November 1982]. These conditions were exacerbated as the regime continued to try to meet IMF requirements for reductions in public spending. Imminent negotiations over the huge per capita external debt augured further austerity measures in 1983. Under these circumstances, many large capitalists also began to view the 'authoritarianausterity' model as an obstacle to continued accumulation, and to opt for a 'democratic' road to capitalism. In late 1982, the PN, representing the large owners' associations, joined the Christian Democrats and some social democratic parties in calling for a return to democracy. Mainly at the initiative of the PDC, the Democratic Alliance (AD) was formed in August 1983. It included, besides the PDC, the Republican, Radical, Radical Democratic, and the Social Democratic Parties, as well as the 'historical', or Allende faction of the Socialist Party (PSCh).

The Christian Democratic Party or PDC has been able to play a pivotal 'centrist' role in the Alliance because of its cross-class bases of support and nationalist, corporatist ideology. Its dominant faction has always sought long-term stability for capitalist accumulation within a framework of modernisation, economic growth, and restricted democracy. Despite occasional conflicts with particular capitalist fractions, the PDC has formed alliances with these fractions to confront threats from the left - as in the $1970-73$ period. The
$\mathrm{AD}$ is thus not only a reaction by the national bourgeoisie to the monetarist regime's attack on its bases of accumulation; it is also a project to prevent the left from extending its hegemony over the growing popular resistance to the military regime. A key element of this strategy has been to divide the left by incorporating its parliamentarist wing into the $\mathrm{AD}$.

The transition scenario set out by the centre-right alliance includes: the resignation of Pinochet; the 'honourable' return of the armed forces to barracks; the election of a constituent assembly; the formation of a provisional government which will exclude the MDP parties; and economic measures to revive industrial and manufacturing capital. These measures represent the maximum concessions which the industrial bourgeoisie contemplates making to the working class. Moreover, the PDC's strategy to oust Pinochet relies upon an alliance with key sectors of the armed forces, and hence on guaranteeing that democracy will be restricted. PDC leaders have explicitly excluded the MDP parties from participation in both the Alliance and in the future provisional government, and have proferred no guarantees that these parties will even be granted legal status.

\section{The Democratic Popular Movement (MDP)}

The MDP, on the other hand - including the Communist Party (PCCh), the Marxist-Leninist wing of the Socialist Party (PSCh-Almeyda) and the Revolutionary Left Movement (MIR) - has elaborated a strategy for democratic transition based on the convergence of the left parties and the formation of a centre-left opposition bloc. Moving from their former tactical view of alliances with petit bourgeois and other social sectors (effected mainly at the level of electoral coalitions), the Communists have adopted a more organic conception of a politico-historic bloc, urging the unification of working class organisations in order to bring about "the eradication of fascism and the deepening of democracy' [Corvalan 1977]. Thus, the PCCh has criticised sectarianism in the trade union movement and declared its commitment to promoting the development of autonomous popular organisations. In practice, at least, the old 'dictatorship of the proletarist' line seems to be giving way to a strategy of progressive democratisation. Also, the relationship between military and political struggle has been redefined in terms which reflect the influence of the Central American experience. The PCCh and the MIR now envisage a mass-based revolutionary movement in which military preparation complements political work. While the latter still carries out vanguardist actions, its admiration for the Central American revolutionary movements has led it to place considerable emphasis on the role of mass organisations and a broad range of forms of popular struggle 
[MIR 1978, 1984]. Notably, the MIR was one of the first organisations of the Chilean left to recognise the importance of mobilising 'marginal' sectors such as shanty-town dwellers and native groups.

The MDP parties have attempted to consolidate a communist-socialist coalition at the level of party leaderships, concurrently with joint actions at the mass base. The PCCh envisages an anti-fascist front encompassing the old Popular Unity parties, the PDC, and other centre and social democratic parties, but within which the left is able to exercise hegemony. This centre-left opposition bloc would seek alliances with 'democratic' sectors of the armed forces, in order to isolate the pro-Pinochet elements. Contrary to the Democratic Alliance's programme, however, the PCCh calls for the democratic restructuring of the military and the dissolution of the secret police. In addition, the economic programme of a provisional government would seek to re-establish the gains made by the working class during the UP period - i.e., the minimal conditions for a programme of progressive democratisation. At present, the MDP appears to enjoy widespread support among the organised, urban working class, and increasingly among shanty-town dwellers, human rights groups, and other communitybased popular organisations.

\section{The Socialist Bloc}

Another group of left opposition parties - the PSChAltamirano, United Popular Action Movement (MAPU), MAPU-worker and peasant (MOC), and the Christian Left (IC) - constitute the socialist bloc. They differentiate themselves from both the social democratic and the Marxist-Leninist currents of the Chilean left. Their analyses of the failure of the UP, of the project of the military regime, and of the existing bases for socialist transition, have been influenced by the anti-dictatorship struggle of the past decade, and by the assimilation of new theoretical currents by their exiles in Europe. Another influence has been the evolution of mass-based revolutionary movements in opposition to military regimes in Central America.

In general, these small socialist parties (called the convergencia socialista because of their goal of reuniting socialists, and eventually all left parties) have criticised the Marxist-Leninist left for failing, above all, to rethink the relationship between democracy and socialism. They explain the defeat of the UP in terms of its inability to consolidate a centre-left hegemonic bloc, pointing to the 'orthodox' left's instrumental approach to class alliances and the 'ultra' left's destabilisation of the government's agenda of gradual reforms. Neither of these approaches to the gradualist strategy, they argue, allowed the middle strata 'space for ideological and political expression' [Rojas 1982].
Middle strata support was crucial because of the narrowness of the UP's electoral base and the extent of bourgeois ideological hegemony. In addition, they are critical of class reductionism - of the failure to link 'non-class' forms of oppression and popular organisation to the working-class struggle.

Because of the experience of 1970-73, the convergencistas place great emphasis upon left unity. However, as we shall see, this goal is not viewed by all tendencies as a precondition for a democratic transition strategy. Their primary theoretical preoccupation is with the question of class alliances particularly with social sectors historically represented by the Christian Democratic and radical parties. Given that Allende's initial electoral victory was due largely to a split in the bourgeoisie, and that the subsequent success of the bourgeois opposition stemmed from the ideological reconvergence of big, medium, and small capital, the convergencistas seek to exploit potential divisions within the centre-right bloc. The tactics they are adopting toward this end, however, diverge, and have profoundly different implications for the outcome of the transition period.

Meanwhile, the two main opposition blocs - the AD and the MDP - are both attempting to incorporate the convergencistas into their respective projects. The balance of forces shifted in favour of the Alliance when the SB joined it in Fall 1983. This occurred when mass resistance to the regime was escalating and provoking violent confrontations with the military. In August, Pinochet sent 18,000 troops into the streets of Santiago to suppress the fourth national day of protest. Twenty-six people were killed, 100 wounded, and more than 1,200 arrested. Participating in these protests was the National Workers Command (CNT), representing almost all organised workers, and headed by the leader of the Copper Workers Confederation. Soon afterwards, the junta passed a security law allowing the government to jail or exile those accused of calling protests. Pinochet also attempted to divide the bourgeois opposition through 'apertura' (opening) talks with AD leaders. These talks collapsed when the junta stated that it had no intention of speeding up the schedule for democratic transition. Thus, threatened by the upsurge of militant working-class opposition, and by a loss of credibility following the (no) 'apertura' talks, the Christian Democrats sought to enhance the AD's 'popular dimension' by incorporating the socialist bloc. Why, however, did the SB agree? To explain this it is necessary to examine the origins and objectives of the two strategic tendencies within the SB.

\section{The 'PCI tendency'}

Within the 'convergency' sector of the Chilean left there is a tendency (currently predominant), which we 
call the 'PCI tendency' (after the Italian Communist Party). Its roots are in the PSCh, which since the 1930s has defined itself as a 'national-popular movement' with a mass base among white-collar workers, intellectuals, and professionals, as well as traditional sectors of the proletariat. The socialists participated in various popular fronts before the UP period, although by the 1970 s a Marxist-Leninist wing of the party was becoming critical of its parliamentarianism. Even the party's left wing, however, differentiated itself from the PCCh by seeking a more diversified class base, and advocating international non-alignment.

Following the coup, many socialists sought asylum in western Europe, where the 'Chilean road to socialism' was a central topic of debate, particularly in Italy. The positions of the PCI appealed to Chilean socialists in key respects. Berlinguer agreed with them that the main failure of the UP was not inadequate preparation for armed confrontation, but the lack of consensus within the left on the necessity to 'avoid the welding of a solid and organic bond between the center and the right ... and instead [to] succeed in drawing the social and political forces in the center onto consistently democratic positions' [Berlinguer 1973]. With the objective of resurrecting the 'Chilean road to socialism', but on the new terrain of a mass-based anti-fascist opposition movement, Chilean exiles initiated the 'socialist convergence' movement in Rome in 1979.

As we shall argue, the SB and the PSCh-Allende have adopted a strategy similar to the PCI's 'historic compromise', which, though drawing upon Gramscian concepts, neglects key elements of his revolutionary theory. The Chilean 'PCI tendency' has defined the present alternatives as either continued military rule or subordinate participation in a bourgeois-led opposition movement. The SB's entry into the centreright Alliance, and its acceptance of the AD's terms for transition, do not lay the basis for a left hegemonic bloc as envisaged by Gramsci. The influence of the PCI is thus crucial to an understanding of the SB's current strategy.

For Gramsci, the formation of an historic bloc, in which the working class exercises hegemony over its allies and simultaneously dominance over its enemies, was the primary task of the revolutionary forces. Only by reference to an overall hegemonic strategy on the part of the left is it possible to distinguish between the self-restraint of the proletariat in pursuing its economic-corporate demands, in order to effect organic alliances, and the simple subordination of workers' interests for the sake of tactical alliance with the bourgeoisie. The PCI's electoral strategy has failed to create an historic bloc, because the lowest common denominator of agreement - opposition to fascism and, subsequently, to monopolies and imperialism did not constitute the grounds for more than a tactical alignment. Moreover, while Gramsci argued the need for a two-pronged strategy, relying not only upon 'siege warfare', but also upon tactical use of force at specific junctures, the PCI has repudiated any form of armed struggle, and most types of struggle that are not exclusively electoral and parliamentary.

The PCI's interpretation of events in Chile also conformed to this distortion of Gramsci's analysis. The basic flaw in the UP's strategy was identified as the failure to effect a compromise agreement with the national bourgeoisie. The tragic outcome of bourgeois counter-revolution and imperialist intervention was transposed to the Italian context. The PCI argued for an alliance with the Christian Democrats to isolate and defeat fascist elements, and to avert possible destabilisation by US imperialism. In short, the key lesson which the PCI derived from its reflections on Chile was the need to make alliances with parties of the centre-right, in order to implement a programme of gradual reforms; whereas the lesson that the PCI should have derived from the Chilean experience - if Gramsci's analysis had been adequately applied to it - was the danger of confusing unstable electoral coalitions with power based on the ability both to lead and to dominate. The UP had not achieved a hegemonic position when it assumed office. Its subsequent failure to build a hegemonic bloc, through a parallel strategy of structural reforms and popular mobilisation, is the key to understanding the bases of the military coup.

The specific elements of this failure are too complex to be discussed here, although chief among them is the left's inability to establish an indissoluble bond between socialism and democracy. The military question can, from this perspective, be reduced to two hypotheses: either the armed forces must be viewed as the monolithic instrument of the bourgeoisie, in which case there was never any possibility of a left government achieving a fundamental shift in the balance of class forces on the basis of a solely electoral victory; or, there existed bases for exploiting splits within the armed forces through successful propaganda work and the demonstration of mass support for the government. In this case, reactionary elements might have been isolated, and the military democratised from within. In the context of the current antidictatorship struggle. we would argue, there are still important lessons to be derived from the 1970-73 period.

Within the socialist bloc it is the 'PCI tendency' that has led the bloc into the Democratic Alliance. In their eagerness to win sectors of the bourgeoisie away from the authoritarian-austerity regime of the military and 
financial oligarchy, these socialists have supported the construction of a centre-right bloc. The Alliance's terms for a democratic transition, outlined above, have been defined by big capital, and its strategy relies not on profound, sustained mass mobilisation, but on the tactical use of overt protests combined with overtures to selected elements of the armed forces. The PCCh has been excluded because of its refusal to rule out armed struggle against the regime. Socialist participants in the $A D$, moreover, have joined in the condemnation of such 'anti-democratic' tendencies of the MDP parties [Molina 1983].

Like the $\mathrm{PCI}$, the socialists in the AD argue that they are constructing a broad anti-fascist front, which serves to isolate the most reactionary sectors of the military, monopoly capital, and foreign imperialism. But while they have made a 'strategic union with the political centre' their key objective they have not created the minimal conditions for a hegemonic strategy [Molina 1983]. This would mean, among other things, a prior convergence of the left. In this respect, socialists in the $A D$ are repeating the errors of the parliamentary wing of the UP. They have focused on party alliances, both in the PDC-led opposition bloc and with respect to a future provisional government. While they claim to be in a position to win away populist-Christian sectors of the PDC's base, it could be argued that they would be in an equally strong position to do so without any formal alliance with the centre-right. The Church's sustained opposition to the regime has created bases for mutual action and theoretical convergence between Marxist parties and popular, religious, and human rights organisations.

Indeed, the Chilean 'PCI tendency' might well have learned from the experience of the PCI in relation to the post-1976 Christian Democratic Government in Italy. According to Napolitano, a major element of the (Italian) Christian Democrats' strategy lay in 'exploiting anti-communist sentiments and the distrust and fear of a part of the electorate and the middle classes ... [while] it succeeded in arousing in the most progressive part of its own electorate hope and faith in the possible renewal of the Christian Democratic Party' [Hobsbawm 1977]. Similarly in Chile, to the extent that the AD establishes a 'national consensus' on the terms of democratic transition, one may predict that this will serve to legitimate a bourgeois and not a socialist hegemony. In contrast to the socialists' scenario of progressive democratisation, the Christian Democrats have quite a different view of the outcome of the transition. Andres Zaldivar, a leader of the PDC, has stated that: "the democracy that is sought must be the same, democracy for democracy and not for changing the rules of the game afterward' [Zaldivar 1983].

\section{A democratic socialist alternative?}

Thus, outside the MDP the majority of Chilean socialists seem to believe that the only way to overthrow Pinochet is to accept temporarily the hegemony of the bourgeois opposition. There is another tendency within the SB, however, which has articulated an alternative strategy for transition on terms more favourable to a socialist transformation. MAPU and the Christian Left (IC) have been calling for some time for new forms of political struggle, breaking with both reformism and guerrilla 'foquism'. They emphasise the promotion of autonomous popular organisations, mobilised around grass-roots concerns, which will gradually achieve higher levels of regional and national co-ordination. These organisations are to be encouraged to adopt 'mixed' forms of struggle, and to view armed defence as a legitimate right. One such organisation, associated with MAPU, is consciously modelled on the Salvadorean Bloque Popular Revolucionario. The Chilean Bloque Popular Unitario participates in strikes, civil disobedience, human rights support work, and organising committees of the unemployed, shanty-town dwellers, women, and other sectors outside the traditional base of the proletarian vanguard parties [BPU 1983, MAPU 1974].

Despite the MAPU-IC position that left convergence is a priority, their differences with the MOP parties appear to be sufficiently great to prevent them, at this stage, from uniting. Meanwhile they are seeking consensus on the nature of the socialist project particularly on the strategy of alliances with segments of the petite bourgeoisie, 'marginal' sectors, and medium capital - and are focusing on convergence at the mass base. MAPU, like the MDP, has called for a complementary development of military and political struggle, evolving from the advance of the popular organisations themselves. The MAPU-IC tendency is also preoccupied with the struggle for intellectual and moral leadership in the formation of an historic bloc - including the study of authoritarian modes of domination, and the bases for the fusion of marxism and liberation theology.

What sets the MAPU-IC tendency apart from the 'PCI tendency' is its appreciation of the conditions for constructing an opposition movement in which working class organisations exercise hegemony. Not surprisingly, they have looked to the Nicaraguan and Salvadorean revolutionary strategies for practical models. While they recognise the crucial differences in class structures and popular cultures between the two contexts, MAPU and the IC appear to have concluded that the fundamental tasks elaborated in Gramsci's revolutionary theory are valid for Chile, too. Once the unity of the left and its hegemony within the popular organisations have been consolidated, the next stage 
of struggle should focus on political activities directed toward those petit-bourgeois sectors allied to centreright parties. The eventual goal - again echoing the strategy of the Central American movements - is the formation of 'a democratic, popular and revolutionary government'. MAPU emphasises, however, that this can only be achieved on the foundation of a revolutionary historic bloc. Thus, the logic of MAPU's position indicates an alternative to the SB's current strategy of alliance with the PDC.

\section{Conclusions}

The two strategies elaborated by the 'PCI' and 'historic bloc' tendencies derive from a shared critique of orthodox Marxist-Leninist praxis, and from a commitment to a democratic socialist resolution of the current struggle. Nevertheless, they have profoundly different implications. We have argued that the socialist bloc's strategy of alignment with the centreright opposition bloc reproduces errors made by the parliamentary socialists within the UP, as well as those of the PCI's 'historic compromise' strategy. The likely outcome of the path to transition envisaged by the Christian Democrats is, to use Gramsci's term, a 'passive revolution', that is, a transfer of power within the ruling class to make possible a restructuring of the mode of accumulation [Gramsci 1971]. Without a dismantling of the repressive apparatus, and given the restricted democracy to which the PDC is committed, there will be little room for manoeuvre by the left. While there may be a lifting of repression, the fundamental questions of power remain unresolved. The left must eventually confront the problem of creating forms of revolutionary organisation capable of carrying out a transition to socialism. The alternative is to revert to a purely electoral strategy on terrain even less favourable than that which brought the UP to office in 1970.

As for the strategy outlined by MAPU and the IC, it clearly envisages a longer-term struggle to remove the military regime, which may be beyond the endurance of a people longing for a non-violent deliverance from an 1l-year reign of terror. The influence on the MAPU-IC line of the Central American revolutionary process also raises the question of whether the 'political-military popular organisations' model is appropriate for Chile. Yet the question is less one of transferring models, than of utilising strategic insights. Obviously there are important differences between the two contexts, but the preoccupation with the conditions for creating hegemony - for constructing a true politico-historic bloc - is, we would argue, an essential starting point for the development of a successful socialist strategy in Chile, as it has been in Central America.

\section{References}

Berlinguer, E., 1973, 'Reflections after events in Chile', Rinascita (Italy), Sept-Oct

Bloque Popular Unitario de Chile, 1983, Poder Obrero (Publicacion Sobre Chile de la Organizacion Combat), numero doble 19-20, Julio-Sept

Business Latin America, 1982, 'Business outlook in Chile', May, p164

Chossudovsky, M., 1977, 'Capital accumulation in Chile and Latin America', research paper no 7709, Dept. of Economics, University of Ottawa, December

Corvalan, L., 1977, The Chilean Revolution, the Fascist Dictatorship, and the Struggle to Overthrow it and Create a New Democracy, report of plenary session of the Central Committee of the Communist Party of Chile, August

Gramsci, A., 1971, Selections from the Prison Notebooks, Q. Hoare \& G. N. Smith, eds., International Publishers, New York, pp58-9, 107-20

Hobsbawm, E., 1977, The Italian Road to Socialism: interview with Gregorio Napolitano, Journeyman Press, London, p 102

MAPU, 1974, Chile: experiences and lessons of the revolutionary struggle, pp 16-21, 31-2

MIR, 1978, Chilean Resistance Courier, no 8, July. The shift in the MIR's position is reflected in post 1977 bulletins and in inter-party agreements such as the August 1977 MIR-UP accord.

-1984, Declaration of the Movement of the Revolutionary Left, June

Molina, J., 1983, leader of the MOC, interviewed in the Chilean magazine $A P S I, 15-28$ November, pp20-23

Rojas, A., 1982, 'Crisis y renovacion en la izquierda Chilena', unpublished paper presented at Queen's University, Kingston, Ontario, November

South, 1982, 'Monetarists carry the can in Chile as Pinochet's problems mount', November, p64

Zaldivar, A., 1983, interviewed in APSI, 15-28 November, p7 